\title{
Students' Attitudes Towards Research and Dissertations in a Mexican Southeastern University
}

\author{
Actitudes hacia la investigación y la elaboración de tesis de alumnos de \\ licenciatura en una Universidad del Sureste de México
}

\section{Atitudes em relação à pesquisa e desenvolvimento de teses de estudantes de graduação de uma universidade do sudeste do México}

Martha Lorena Obermeier Pérez

Universidad Autónoma de Chiapas, México

lorena.obermeier@gmail.com

https://orcid.org/0000-0002-8500-0776

\section{Resumen}

Investigaciones realizadas en ámbitos universitarios se han enfocado en estudiar el síndrome todo menos tesis. Existen numerosas evidencias de que este problema persiste en diversas instituciones educativas en países Latino Americanos. Las intervenciones realizadas no han tenido los resultados esperados. El objetivo de este estudio realizado en una Universidad del Sureste de México fue medir la actitud que los alumnos de una licenciatura presencial tienen hacia la investigación. Se pretendió determinar si tanto los docentes como las condiciones institucionales fomentan este tipo de actividades. Estos conceptos habían sido medidos anteriormente en un estudio previo en la modalidad virtual del mismo programa. Este estudio fue mixto de tipo convergente con la variante de cuestionario y se eligió una muestra no probabilística. Este enfoque fue utilizado para comprender las razones por las que se niegan a escribir una tesis.

Los resultados muestran que un alto porcentaje de los alumnos no contempla la opción de titularse por tesis y prefiere otras modalidades aceptadas por la institución. Se determinó que la actitud hacia la investigación es baja, que los docentes del programa no realizan investigación y que la tutoría que ofrecen en este tipo de trabajos no es adecuada. Igualmente, se encontró que las 


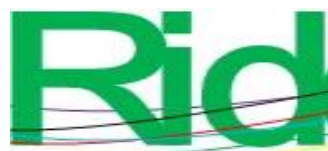

condiciones institucionales tampoco fomentan las actividades de investigación. Si bien los alumnos consideran importante este tipo de formación, desconocen la existencia de cuerpos académicos y no se les incluye en este tipo de proyectos. Se concluye que es necesario realizar estudios en otras facultades para determinar si el problema prevalece en el resto de la institución. También se recomienda fomentar la formación en investigación de los docentes que imparten las materias de metodología en el programa.

Palabras Clave: Todo Menos Tesis, Investigación, Formación de Investigadores.

\section{Abstract}

Research conducted in universities has been devoted to the "All but Dissertation Syndrome" (ABD). Some interventions have been made to encourage students to write a dissertation, but the results have not had the expected results. The objective of this study conducted in a Mexican Southeastern University was to measure students' attitude towards research in an indoors program. This study sought to assess if teachers and institutional conditions encourage research activities. These concepts were previously measured in a former study conducted in the online program of the same institution. This was a convergent mixed method study with a questionnaire variant and a non-probabilistic sample. This approach was used to understand the reasons why students refuse to write a dissertation. The instrument was designed to measure students' attitudes towards research, their willingness to write a dissertation; their opinions about the institutional conditions.

The findings suggest that the attitude towards research is low, professors do not conduct research and the tutoring they provide in this kind of activities is not adequate. It was also determined that the institutional conditions do not encourage research activities. Even if the students consider that these skills are important, they ignore the existence of research groups and they are not invited to participate in their projects. The evidence supports the notion that future research will have to confirm whether this problem persist in the other faculties of the institution. It should also be considered to encourage research training for the professors who teach methodology related subjects in the program.

Keywords: All but Dissertation, Research, Training Researchers. 


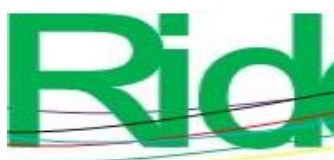

\section{Resumo}

A pesquisa realizada em ambientes universitários concentrou-se no estudo da síndrome, exceto a tese. Existem inúmeras evidências de que esse problema persiste em várias instituições de ensino nos países da América Latina. As intervenções realizadas não tiveram os resultados esperados. $\mathrm{O}$ objetivo deste estudo, realizado em uma universidade do sudeste do México, foi medir a atitude que os estudantes de um curso presencial têm em relação à pesquisa. Pretendeu-se determinar se os professores e as condições institucionais incentivam esse tipo de atividades. Esses conceitos foram medidos anteriormente em um estudo anterior na modalidade virtual do mesmo programa. Este estudo foi misto do tipo convergente com a variante do questionário e uma amostra não probabilística foi escolhida. Essa abordagem foi usada para entender as razões pelas quais eles se recusam a escrever uma tese.

Os resultados mostram que um alto percentual de alunos não contempla a opção de se formar por tese e prefere outras modalidades aceitas pela instituição. Foi determinado que a atitude em relação à pesquisa é baixa, que os professores do programa não realizam pesquisas e que a tutoria que eles oferecem nesse tipo de trabalho não é adequada. Da mesma forma, verificou-se que as condições institucionais também não incentivam as atividades de pesquisa. Embora os estudantes considerem esse tipo de treinamento importante, eles desconhecem a existência de órgãos acadêmicos e não são incluídos nesses tipos de projetos. Conclui-se que é necessário realizar estudos em outras faculdades para determinar se o problema prevalece no restante da instituição. Também é recomendável promover o treinamento em pesquisa de professores que ensinam a metodologia no programa.

Palavras-chave: Tudo menos tese, pesquisa, treinamento de pesquisadores. Fecha Recepción: Octubre 2018 Fecha Aceptación: Septiembre 2019 


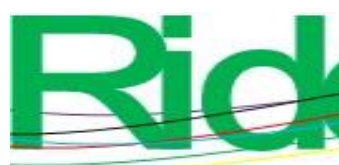

Revista Iberoamericana para la

Investigación y el Desarrollo Educativo

ISSN $2007-7467$

\section{Introduction}

Education is a key factor to developing countries, which allows them to avoid poverty, create progress and improve the lifestyle. Since their beginning, universities have been dedicated to teach, to administrate and to work on research activities. Before 1990, the most developed activity was teaching. The administrative models of universities in Latin American countries were transformed into an academic evaluation model. In Mexico, programs were developed to improve the number of scientific products and raise teachers' salary for those who conducted research (Pérez \& Guzmán, 2015). These programs changed the focus or main aim from teaching to research activities.

In addition to this change related to the activities, teaching has been modified by the competencies approach, which is closer to teachers needs and demands an interdisciplinary organization of contents. The challenge is to modify the teachers' culture (Gairín, 2011). Even if Mexican curricular programs have been designed according to the international standard competencies approach, they have not been completely implemented. One of the reasons is that this approach requires resources that institutions do not have and training teachers who seem to be reluctant to this change. The competencies approach has not been welcomed and the transition has been slow in all the educational levels.

Mexican universities need professors who conduct research and encourage students to research in the undergraduate programs. Unfortunately, Mexican universities authorize several options to obtain a degree. Students fulfill the curricular program, but need to write a dissertation to obtain the degree. Other options are that the degree is given if they have those considered the maximum grades; they also have the opportunity to take a proficiency-achievement exam; write an activity journal made throughout their social service (internship) period or start a Master's Degree and obtain the BA title within this second completion. Even with all these options given, only a low number of students can obtain their degree and therefore raise the statistics of these programs. These options help raising numbers, but affect the students' attitude towards research and their willingness to write a dissertation.

Programs are not considered efficient if the number of students that obtain a degree is considerably low compared to those who complete the curricular program. One of the consequences of this problem is that college students do not have the necessary knowledge for those roles demanded by the job market. In this global society, only the best trained people will 


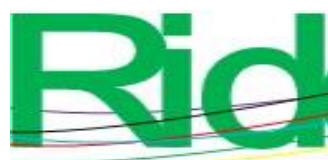

Revista Iberoamericana para la

Investigación y el Desarrollo Educativo

ISSN $2007-7467$

have the best opportunities to succeed. Students that are not able to write a dissertation and conduct research in their field, question the quality of the program and its social needs. Students who obtain a degree by writing a dissertation have better opportunities, job offers, scholarships and salaries (Ochoa, 2011).

Professors in Latin American universities have experienced what has been named the "All But Research Syndrome" (ABR), which refers to the teachers who have refused to modify their academic activities and conduct research. For the students who refuse to write a dissertation, the term applied has been "All But Dissertation" (ABD). The objective of the study conducted was to measure the attitude that students of a Bachelors' Degree in ESL Teaching have towards research. This was a purposeful sampling with students of the last semester who had already taken the courses related to research. They were near to graduation and were questioned about their intention to write a dissertation, the reasons to choose another modality, their opinions about the teachers and about the institutional conditions.

Before this study, a similar one was conducted in the online BD in ELT of the same institution. This was a correlational study and it was found that a deeper insight from students was necessary to understand the reasons why they do not consider writing a dissertation. It was concluded that students have low attitude towards research and they consider that the teachers and the institution do not encourage them to conduct research (Obermeier, 2017). The present study was conducted to provide a deeper insight of the phenomenon and evaluate if this situation prevails in the indoors program of the same institution.

\section{All but Dissertation Syndrome}

In the literature review, several studies related to the ABD syndrome, researchers' training and the importance of research were found. In 1994, Dr. Elizabeth Valarino published a book in Venezuela called: All but Research, which gave roots to many researches working in this area. This researcher states that a student does not present a dissertation due to three main factors: cognitive (skills and knowledge related to research processes), affective (internal locus, persistence, blocking, perfectionism, customs, low self-esteem) and social (procrastination, isolation) (Valarino, Yaber \& Cemborain, 2011). Other studies found were focused on the works of Mexican researchers. Pérez-Reveles, Topete-Barrera and Rodríguez-Salazar (2014) mention that the process of training a researcher is complex and they present a comparative chart of the different models of training. In today's Mexican context, new researchers have to choose between publishing, 


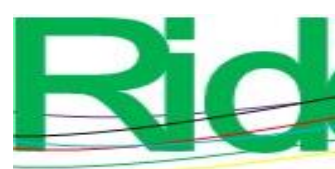

Revista Iberoamericana para la

Investigación y el Desarrollo Educativo

ISSN $2007-7467$

developing new products, teaching or training new researchers.

Uribe, Márquez, Amador and Chávez (2011) have also conducted research in the area and state that the options authorized by educational institutions to obtain the degree raise their numbers, but hinders the development of research. In Mexico, there are a few researchers and the institutional practices do not encourage students to conduct a research while offering other vias. It is also important to modify the way research methodology is being taught, this should be a space for learning and collaborating, spaces where students learn how to conduct research while researching. Gutiérrez (2014) states that training researchers is not limited to develop some specific skills, but the learning context should also be considered. Bandura's socio cognitive theory states that behavior reflects interaction and reaction to social agents that influence personality. The components of this theory are modeling, internal processes activation and independent behavior. These three elements should be combined with a pragmatic approach to motivate students in the research process, instead of presenting research as something mandatory to obtain a degree (Kranke, Brown, Atia \& Knotts, 2015).

For Bandura (2000), learning takes place at experiencing directly the effects of your own actions and through modelling. In the socio cognitive model, behavior, personality and context interact and influence each other. Bandura is considered the leading theorist of observational learning, which is based on the idea that learning is the product of social interactions. Observational learning involves language, thinking and the self-regulation of one's behavior. Experiences observed in another person impacts the person's own behavior. The models will be followed if they are considered similar to oneself, are respected, have a special status, have high competence, are powerful or attractive. People follow effective models and ignore those presumed ineffectual (Olson \& Hergenhahn, 2013).

Higher thinking skills such as those needed to conduct research are developed in context where learning is encouraged, it implies a challenge and the context provides adequate conditions. Vicarious learning occurs when the models around us are considered similar to us, this type of learning is one of the main elements in Bandura's approach because it is an effective way to modify behavior. Events of the context act as models that affect personality and behavior. In general, people observe, imitate and model behavior based on what they observe on others (Deaton, 2015). When students have appropriate models, they imitate the activities, develop new skills, improve their thinking abilities and analyze problems using the scientific method (Kranke, Brown, Atia \& Knotts, 2015). Bandura considers that teachers are models with virtues, they condition students in 


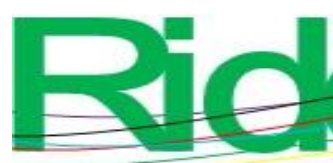

Revista Iberoamericana para la

Investigación y el Desarrollo Educativo

ISSN $2007-7467$

a manner that they imitate their roles. This has a direct impact in the construction of the professional self-concept (Sanderse, 2013).

Students' motivation diminishes when their teachers are not competent or do not model certain activities. Having good models improves self-efficacy and helps the development of knowledge and skills. Teachers can only develop students' skills that they have already developed. Self-efficacy builds self-concept that influences the choice of activities and the commitment to perform those activities. Low self-efficacy causes stress and diminishes the use of abilities as it focuses on deficiencies and negative results instead of focusing on strategies that can help accomplish objectives. Self-efficacy refers to the beliefs of what one is capable of doing and it is formed from a variety of sources, personal accomplishments and failures or seeing others succeed or fail at doing a task. Persons with high perceived self-efficacy experience less fear, try more, accomplish more and persist longer doing a task.

People with low self-efficacy avoid performing difficult activities as they perceive them as a menace, they have low aspirations and lack of commitment to accomplish objectives. They focus on their insecurities and fears instead of looking for strategies to be successful. On the contrary, people who trust their self-efficacy set more difficult challenges and visualize positive results as they have more cognitive resources, flexibility to modify their strategies and are efficient at managing the context. They consider obstacles as challenges to conquer and they are usually interested in their activities and are committed to perform them. They focus on the task and not on themselves, which motivates them to accomplish objectives that raise their motivation. This is one of the reasons why instructional designs that increase students' self-efficacy have a positive impact on students' interest to conduct research (Kranke, Brown, Atia \& Knotts, 2015).

\section{Research in the Universities}

An aspect considered to determine the quality of the universities is their professors' academic production. Universities' prestige and excellence are based on the quantity and quality of their research. Even if universities have always had the functions of teaching and research, Latin American universities have always had little scientific productions (Gascón, 2008). In recent years, international educative policies tend to involve teachers in research activities and try to improve the quality through training researchers (Reyes \& Hernández, 2014).

The administrative model in the universities was modified after 1990 and became a model of academic evaluation. Organizations like National System of Researchers (SNI) and the Program 


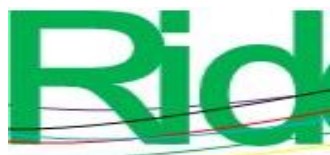

for the Professional Development of Professors (PRODEP) were created to improve the conditions of the scientific production in Mexico and raise the salary of the teachers who conduct research (Pérez \& Guzmán, 2015). After this academic transformation, research has been considered more important and has been encouraged in universities. To encourage research and provide the appropriate conditions, several elements are combined: macro level elements (national policies, financial conditions, national and local needs) and micro level elements (institutional policies, academics' credentials, infrastructure, training programs) (Moreno, 2012).

Even if these organizations were created to encourage research, raise salaries and recognize researchers, it has also created conflicts in the educational institutions. The roles of teacher and researcher do not always go along, which can isolate the researcher, lack of teachers' promotion and losing universities' prestige (Frugoni, 2014). For many professors, educational institutions have become toxic, due to the competitively demands to produce, to stay in the institution and having the same income (Pérez \& Guzmán, 2015). Researchers who belong to these organizations are forced to produce because they need high levels of production. This policy has a negative impact in the quality of their products and sometimes provokes a competition between researchers of the same institution.

The demands of these organizations have also generated negative feelings towards research, such as guilt, jealousy and anger, which can emerge when researchers establish interpersonal relationships, when production compromise academic status and the scientific image or respect of the researcher (Rietvieldt \& Vera, 2012). Some teachers have not been promoted or offered economic stimulus because they refused to conduct research. This is sometimes due to the fact that they do not have the appropriate training or the skills to research. Besides, some teachers consider that writing a research paper is a long and lonely path.

Professors are evaluated not only by the SNI, but they are also asked to work in Academic Research Groups (CA) with coworkers who do not have the same skills or training to conduct research (Pérez \& Guzmán, 2015). Teachers have traditionally been devoted to teach in classrooms, so researching and working in these groups present several challenges: lack of skills to work in teams, lack of acceptance to have a leader, role conflict, competitively and lack of cooperation. Even with all these challenges, being part of one of these groups offers a status among the academic society because it is an institutional and international figure, a backup when demanding funds and an indicator that research is being conducted. For teachers to be hired in institutions, doctoral degrees, international publications and projects that obtained grants are required. 


\section{The Importance of Writing a Dissertation}

Having ABD students proves that an academic program is not efficient and is one of the aspects considered when programs are qualified. This situation has increased in several universities because other options to obtain a degree are accepted, but even having these options, the number of students who obtain a degree is still low. There are several variables that influence and generate the ABD students. Some of them are lack of help from teachers, who do not have time to research or do not have publications or research topics developed (Valarino et al., 2011). As these teachers do not have publications or research topics, they are not able to develop students' research skills.

The ABD syndrome is a group of symptoms experienced while designing, planning, developing, writing, reviewing and publishing research papers or long term projects. The behaviors that evidence this syndrome are procrastination, negative self-dialogue, negative habits, lack of time and work structures, anxiety towards unaccomplished targets and writing blocks. The blocking is a defense system activated in order to release the tension when facing a long task. It is also a strategy to manage negative ideas, fear to be criticized, to fail or self-perfectionism. All these feelings are also experienced when conducting research.

In interventions made to solve the ABD syndrome, it has also been observed that students are not used to work under pressure, they feel themselves unable to perform the activities related to writing a dissertation, which they solve by looking for excuses or blaming others (Abousky et al., 2012). Students writing a dissertation can experience negative feelings, isolation, anger, anxiety and nervousness at the beginning. These feelings diminish as they work on their projects and they feel more confident about performing the task. The feelings of not being discovering anything new and that everything has already been said affect the self-esteem and can make the student drop the task (Ochoa, 2011).

\section{Adequate Conditions for Research}

Institutional conditions are an important factor for training researchers, which is a complex process. The difficulties of the context and institutional social and political factors influence training researchers and must be considered. Research must be considered as a necessary element for learning, the conceptual idea of it is a determinant factor of the attitude towards research (Uribe et al., 2011). Researchers claim that this is an outcome of the activities they did to learn how to conduct research. This is the reason why the best scenario to train researchers is conducting research (Gutiérrez, 2014). According to this idea, teaching courses of research methodology is a 


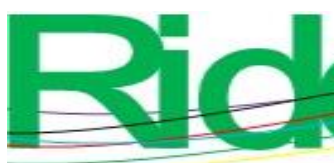

Revista Iberoamericana para la

Investigación y el Desarrollo Educativo

ISSN $2007-7467$

failure if they are not surrounded by the appropriate context that encourages research.

Attitude and motivation are important factors needed to write a dissertation. Institutional conditions like tutoring, library access, internet connection and access to resources are other factors that encourage research (Rietvieldt \& Vera, 2012). Many researchers recommend to teach how to research while conducting research, learn with an experienced researcher, integrate theory of research and practice and this is a slow process to develop in any academic level and in any part of the world (Spinzl, Sosa, González \& Aquino, 2015; Pérez-Reveles et al., 2014). Another important element is the teachers, who develop skills, attitudes and ethics towards research.

Besides the institutional conditions, complex cognitive abilities are needed such as selecting a topic, having an open attitude, being motivated and having the time and appropriate resources. In many cases, to write a dissertation requires skills that have not been developed before like willingness to continue despite failure, tolerance to ambiguity and developing unfamiliar writing skills. Writing is one of the most complex skills to develop because it demands to write a coherent text to explain a process followed. This was the main skill to develop in many of the interventions found in the literature reviewed. These interventions designed courses and workshops to teach academic writing, reduce the blockings and improve the writing productions.

Writing is one of the most important activities for professors, publications are a factor considered for hiring, promotion and staying in academia. Teaching and administrative activities are a distraction that takes professors away from writing. People who write make time for it and write in spite of being blocked or not feeling like it and have more creative ideas than those who write when they are inspired. Writing also reduces insecurities and improve social status, it depends on constant work and habits and it helps to clarify ideas and explore the relationship between them. It is an auto didactic activity that demands concentration on a complex task.

Teaching to conduct research and to write about research is a worldwide problem. A teacher who only teaches and does not conduct research, loses opportunities for promotions and has a low salary because the evaluation systems considers publications as quantifying products (Pérez \& Guzmán, 2015). Research develops cognitive abilities, transforms attitudes and teaches values (Uribe et al., 2011). A student who is motivated writing a dissertation, will naturally perform activities related to research. The research process should provoque an attitude change towards research so it can be a satisfying activity and, it should be encouraged by the institutional conditions (Rietvieldt \& Vera, 2012). 


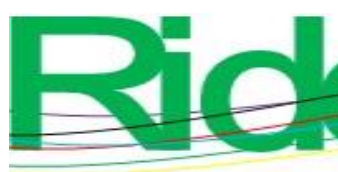

Revista Iberoamericana para la

Investigación y el Desarrollo Educativo

ISSN $2007-7467$

During this process, a student also needs to be close to the Chair person. The success of a dissertation depends on the characteristics of the Chair, the characteristics of the student, the relationship Chair-student and the institutional conditions. A dissertation is considered as a demanding and long task, a Chair that structures the task can help change that misconception. A Chair must be experienced, open to discussion, have emotional stability, have constructive ideas, offer updated information and have established appropriate areas of research.

The students who have high probabilities of finishing a dissertation are those who have had some experience with research and who already have a research question. Students who conduct a project based on a topic provided by the Chair have low probabilities of finishing. Today policies state that professors should be researchers, accreditation criteria evaluate if students write a dissertation. As it has been stated before, even if research is a long and complex process, it is demanded and supposed to provoke a conceptual transformation (Ochoa, 2011).

\section{Method}

This is a convergent mixed method study with a questionnaire variant that included two open-ended questions and several Likert scale questions to measure the variables related to attitudes towards research. According to Hernández, Fernández and Baptista (2014), a mixed method study is suitable to a problem that has not been deeply studied. A convergent mixed method study is used to compare results of the two approaches to obtain deeper understanding of a problem and validate one set of data with the another (Creswell \& Plano Clark, 2018). This approach helped to understand the reasons why students in the cohort will choose to write or not a dissertation and their attitudes towards research. The qualitative answers provided emergent themes to validate the survey findings. The two different strands of data were collected in a single phase and the results were merged to look for convergence, contradictions and relationships.

The three research questions of the study were: what are the students' reasons for not writing a dissertation? how do students feel about research, teachers and the institutional conditions? to what extend are willingness to write a dissertation and attitude towards related research? The hypothesis was that students in the indoors program would have a more positive attitude towards research and more willingness for writing a dissertation than the online students, as a result of the closer contact with role models and the immersion in the institutional conditions. 


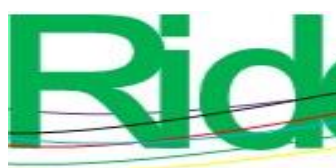

Revista Iberoamericana para la

Investigación y el Desarrollo Educativo

ISSN $2007-7467$

The first two questions of the instrument were about the modalities preferred to graduate and the reasons that influenced their decision about writing a dissertation. The Likert scale questions measured four variables: attitudes towards research; usefulness of research in their professional life; anxiety or difficulty related towards research. Questions with a semantic differential were included to detect unconscious attitudes. Other questions to know the students' opinions on their teachers and the institutional conditions were included. A non-probabilistic, convenient sample was used. It was formed by 12 of the 15 students in the last semester of the BA program, which represents an $80 \%$ response rate. The Cronbach's Coefficient was $82 \%$ so there is reliability in the results.

The results of the first two open-ended questions informed that $61.11 \%$ of the students would not consider writing a dissertation and only $38.89 \%$ has considered it as an option to obtain the degree. Regarding the reasons for not writing a dissertation, students answers gave an insight about how they perceive writing a dissertation. Two students mentioned that they do not have the time needed to write such a long work. Two students mentioned that they can obtain the degree because of their good grades. Two other students have considered to get a Master's Degree. One of the students mentioned that writing a dissertation implies having high expenses and economy was the main reason for not considering it as an option. One student mentioned that conducting research is complicated and did not feel able to conduct it. Another student mentioned a factor not considered before conducting this study: the complexity of the task and the time needed for revisions and the administrative process after writing the dissertation.

The rest of the questionnaire had 28 questions: 7 about their feelings and opinions towards research; 9 questions with a semantic differential; 8 questions about the institutional conditions and 4 about their teachers. The information was analyzed with tables of frequencies and quartiles to classify attitudes in low, medium or high. It was found out that $78 \%$ of the students consider that research methodology should be taught to all of the students. $45 \%$ do not want to study this subject because they considered it difficult and complex. 11\% enjoys doing this type of assignments and $16 \%$ considers it interesting. $78 \%$ think it will be useful for their professional life, but only $8 \%$ are interested in doing research in the future. Even if $93 \%$ considers it valuable, only the $44 \%$ is considering to conduct research in their professional life.

The scale to measure attitude towards research was obtained with the answers to the Likert scale questions and the results are presented in table 1. The minimum was 45 and the maximum was 70 in a 100 scale. The quartiles are presented in table 3: 33\% has a low attitude, $42 \%$ has a 
medium attitude and $25 \%$ has a high attitude towards research.

Table 1. Frequencies of the ATR

\begin{tabular}{|c|c|c|c|c|}
\hline Values & Frequency & Percent & $\begin{array}{c}\text { Valid } \\
\text { Percent }\end{array}$ & $\begin{array}{c}\text { Cumulative } \\
\text { Percent }\end{array}$ \\
\hline 45 & 1 & 8.33 & 8.33 & 8.33 \\
\hline 47 & 1 & 8.33 & 8.33 & 16.67 \\
\hline 51 & 2 & 16.67 & 16.67 & 33.33 \\
\hline 54 & 1 & 8.33 & 8.33 & 41.67 \\
\hline 55 & 1 & 8.33 & 8.33 & 50 \\
\hline 56 & 1 & 8.33 & 8.33 & 58.33 \\
\hline 60 & 1 & 8.33 & 8.33 & 66.67 \\
\hline 62 & 1 & 8.33 & 8.33 & 75 \\
\hline 67 & 1 & 8.33 & 8.33 & 83.33 \\
\hline 69 & 1 & 8.33 & 8.33 & 91.67 \\
\hline 70 & 1 & 8.33 & 8.33 & \\
\hline Total & 12 & 100.0 & 100.0 & 100 \\
\hline
\end{tabular}

Source: Elaborated by the author with the data collected in the research study. 
Table 2. Statistic Data of the ATR

\begin{tabular}{|c|c|}
\hline $\mathrm{N}$ & 12 \\
\hline Mean & 57.25 \\
\hline Interval & 25 \\
\hline Minimum & 45 \\
\hline Maximum & 70 \\
\hline Std. Deviation & 1.33 \\
\hline Variance & 63.68 \\
\hline
\end{tabular}

Source: Elaborated by the author with the data collected in the research study.

Table 3. Quartiles of the ATR

\begin{tabular}{|c|c|c|c|}
\hline & Range & Total & Percent \\
\hline Low & $45-53$ & 4 & $33 \%$ \\
\hline Medium & $54-62$ & 5 & $42 \%$ \\
\hline High & $63-70$ & 3 & $25 \%$ \\
\hline
\end{tabular}

Source: Elaborated by the author with the data collected in the research study.

Regarding the opinion about the institutional conditions, 55\% is satisfied or completely satisfied with the academic and scientific level of the program. Only the $27 \%$ of the students know about the existence of research groups and $8 \%$ has participated in academic or scientific events. $8 \%$ considers that there is a good ambience to conduct research and $22 \%$ considers that scientific development is encouraged, but there are no scholarships or economical prizes to encourage students who conduct research. About the options authorized by the institution to obtain a degree, 
$16 \%$ consider them as an opportunity for not writing a dissertation.

Table 4. Satisfaction With the Scientific and Academic Level of the Program

\begin{tabular}{|c|c|}
\hline Answer & Percent \\
\hline $1=$ Strongly disagree & $5.56 \%$ \\
\hline $2=$ Disagree & $25 \%$ \\
\hline $3=$ Neither disagree nor agree & $8.33 \%$ \\
\hline $4=$ Agree & $36.11 \%$ \\
\hline $5=$ Strongly agree & $19.44 \%$ \\
\hline Total & $100 \%$ \\
\hline
\end{tabular}

Source: Elaborated by the author with the data collected in the research study. 
Table 5. Acknowledgement of the Research Groups

\begin{tabular}{|c|c|}
\hline Answer & Percent \\
\hline $1=$ Strongly disagree & $30.56 \%$ \\
\hline $2=$ Disagree & $13.89 \%$ \\
\hline $3=$ Neither disagree nor agree & $22.22 \%$ \\
\hline $4=$ Agree & $27.78 \%$ \\
\hline $5=$ Strongly agree & $5.56 \%$ \\
\hline Total & $100 \%$ \\
\hline
\end{tabular}

Source: Elaborated by the author with the data collected in the research study.

Table 6. Participation in Scientific or Academic Events

\begin{tabular}{|c|c|}
\hline Answer & Percent \\
\hline $1=$ Strongly disagree & $44.44 \%$ \\
\hline 2 = Disagree & $13.89 \%$ \\
\hline $3=$ Neither disagree nor agree & $27.78 \%$ \\
\hline $4=$ Agree & $8.33 \%$ \\
\hline $5=$ Strongly agree & $5.56 \%$ \\
\hline Total & $100 \%$ \\
\hline
\end{tabular}

Source: Elaborated by the author with the data collected in the research study 
Table 7. Opinion about the Institutional Context

\begin{tabular}{|c|c|}
\hline Answer & Percent \\
\hline $1=$ Strongly disagree & $16.67 \%$ \\
\hline $2=$ Disagree & $44.44 \%$ \\
\hline $3=$ Neither disagree nor agree & $25 \%$ \\
\hline $4=$ Agree & $8.33 \%$ \\
\hline $5=$ Strongly agree & $5.56 \%$ \\
\hline Total & $100 \%$ \\
\hline
\end{tabular}

Source: Elaborated by the author with the data collected in the research study.

Table 8. Institution Organizes Activities to Conduct Research

\begin{tabular}{|c|c|}
\hline Answer & Percent \\
\hline $1=$ Strongly disagree & $13.89 \%$ \\
\hline $2=$ Disagree & $33.33 \%$ \\
\hline $3=$ Neither disagree nor agree & $25 \%$ \\
\hline $4=$ Agree & $22.22 \%$ \\
\hline $5=$ Strongly agree & $5.56 \%$ \\
\hline Total & $100 \%$ \\
\hline
\end{tabular}

Source: Elaborated by the author with the data collected in the research study. 


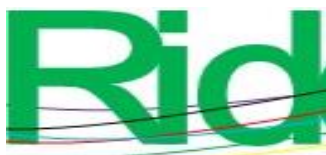

Revista Iberoamericana para la Investigación y el Desarrollo Educativo ISSN $2007-7467$

Table 9. Encouragement of Scientific Development and Economical Prizes for Students

\begin{tabular}{|c|c|}
\hline Answer & Percent \\
\hline $1=$ Strongly disagree & $36.11 \%$ \\
\hline $2=$ Disagree & $27.78 \%$ \\
\hline $3=$ Neither disagree nor agree & $19.44 \%$ \\
\hline $4=$ Agree & $16.67 \%$ \\
\hline $5=$ Strongly agree & $100 \%$ \\
\hline Total & \\
\hline
\end{tabular}

Source: Elaborated by the author with the data collected in the research study. 


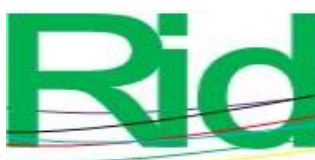

Revista Iberoamericana para la Investigación y el Desarrollo Educativo ISSN $2007-7467$

Table 10. Inclusion of Students in Research Projects

\begin{tabular}{|c|c|}
\hline Answer & Percent \\
\hline $1=$ Strongly disagree & $30.56 \%$ \\
\hline $2=$ Disagree & $47.22 \%$ \\
\hline $3=$ Neither disagree nor agree & $13.89 \%$ \\
\hline $4=$ Agree & $8.33 \%$ \\
\hline $5=$ Strongly agree & $100 \%$ \\
\hline Total & \\
\hline
\end{tabular}

Source: Elaborated by the author with the data collected in the research study 


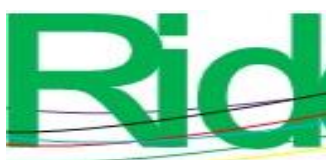

Revista Iberoamericana para la Investigación y el Desarrollo Educativo

ISSN $2007-7467$

Table 11. Options to Obtain a Degree considered as an Opportunity to Avoid Writing a Dissertation

\begin{tabular}{|c|c|}
\hline Answer & Percent \\
\hline $1=$ Strongly disagree & $16.67 \%$ \\
\hline $2=$ Disagree & $25 \%$ \\
\hline $3=$ Neither disagree nor agree & $41.67 \%$ \\
\hline $4=$ Agree & $16.67 \%$ \\
\hline $5=$ Strongly agree & $100 \%$ \\
\hline Total & \\
\hline
\end{tabular}

Source: Elaborated by the author with the data collected in the research study

The $69 \%$ of the students informed that teachers do not use their own research products in the subjects they teach and only $21 \%$ consider that teachers are well trained to conduct research. $71 \%$ considers that teachers do not offer them adequate tutoring while doing research related tasks and $57 \%$ has not participated in their teachers' research projects. 
Table 12. Teachers use Their own Publications in the Subjects They Teach

\begin{tabular}{|c|c|}
\hline Answer & Percent \\
\hline $1=$ Strongly disagree & $19.44 \%$ \\
\hline $2=$ Disagree & $50 \%$ \\
\hline $3=$ Neither disagree nor agree & $8.33 \%$ \\
\hline $4=$ Agree & $16.67 \%$ \\
\hline $5=$ Strongly agree & $5.56 \%$ \\
\hline Total & $100 \%$ \\
\hline
\end{tabular}

Source: Elaborated by the author with the data collected in the research study

Table 13. Teachers Have Good Training as Researchers

\begin{tabular}{|c|c|}
\hline Answer & Percent \\
\hline $1=$ Strongly disagree & $8.33 \%$ \\
\hline $2=$ Disagree & $25 \%$ \\
\hline $3=$ Neither disagree nor agree & $44.44 \%$ \\
\hline $4=$ Agree & $13.89 \%$ \\
\hline $5=$ Strongly agree & $8.33 \%$ \\
\hline Total & $100 \%$ \\
\hline
\end{tabular}

Source: Elaborated by the author with the data collected in the research study 
Table 14. Teachers Offer Adequate Tutoring While Performing Research Tasks

\begin{tabular}{|l|l|}
\hline Answer & Percent \\
\hline 1= Strongly disagree & $27.78 \%$ \\
\hline 2 = Disagree & $44.44 \%$ \\
\hline 3= Neither disagree nor agree & $11.11 \%$ \\
\hline 4= Agree & $16.67 \%$ \\
\hline 5= Strongly agree & \\
\hline Total & $100 \%$ \\
\hline
\end{tabular}

Source: Elaborated by the author with the data collected in the research study

Table 15. Participation in Research Projects of Their Teachers

\begin{tabular}{|c|c|}
\hline Answer & Percent \\
\hline $1=$ Strongly disagree & $44.44 \%$ \\
\hline $2=$ Disagree & $13.89 \%$ \\
\hline $3=$ Neither disagree nor agree & $19.44 \%$ \\
\hline $4=$ Agree & $22.22 \%$ \\
\hline $5=$ Strongly agree & $100 \%$ \\
\hline Total & \\
\hline
\end{tabular}

Source: Elaborated by the author with the data collected in the research study

\section{Discussion}

According to Bandura's socio cognitive theory, the context influences the development of self-concept and at the same time, this context is influenced by people's activities. Based on the results of the study, the institutional conditions do not encourage research activities. Another assumption from the data is that professors are not modelling activities related to research because they lack the necessary skills. The context that does not encourage research and the lack of this activities suggest that teachers as well as students have a low self-efficacy towards research. This low self-efficacy feeling about being able to perform is accentuated with the aspects mentioned by 


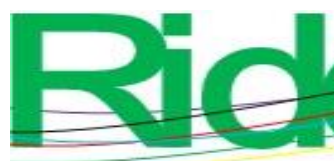

students: time needed, expenses, complexity and administrative processes.

Bandura also considers the reciprocal determinism, the person, the environment and the personal behavioural interact and have influence on each other. This is a three-way interaction that should be understood in order to understand human psychological functioning and behavior. People exposed to high performance standards reinforce themselves for superior performance. This is why teachers should be researchers so they can be good role models for students. This author states that if standards are too high, they can be a source of personal distress and that working on goals too difficult or distant can be disappointing. In general, a dissertation can be perceived as a long and difficult task and only those who have good models and are settle in a god context can accomplish it (Olson \& Hergenhahn, 2013).

After doing the literature review, it is obvious that the influence of the context and of the teachers/models have not encouraged the development of a high self-efficiency in the students. In this study a numeric value was assigned to evaluate the students' self-efficacy, the opinion they have about their teachers and about the institutional context. Several actions are needed to improve the institutional conditions so they encourage research, train teachers to be researchers so they become better models and involve students in projects to change their perceptions of research.

A model can be a person or anything that conveys information, they can be more effective when they are respected, competent, high status and powerful. Teachers can be highly influential models and this is the reason why the opinion of students about teachers was measured in this study. They can model skills, problem-solving strategies, ethical codes, performance standards and creativity. Bandura's theory is called socio cognitive because it emphasizes that most of the information is gained through the interactions with other people.

It is evident that students that do not obtain a degree by writing a dissertation is a problem that affects educative institutions. This problem affects graduate and postgraduate students in Mexico and in other Latin American countries. There is evidence that interventions to solve or prevent the ABD syndrome have had positive results. In a 100 scale, the $70 \%$ is barely satisfactory. Students in the institution have a low attitude towards research. They recognize its importance, the need to conduct research in their professional life and their desire to take more methodology courses. On the other hand, students acknowledge that research methodology is complex and that it demands specific skills.

As this problem has been found in other contexts, interventions have been performed. Cisternas (2013) conducted a case study about teachers' training. This author states that the quality 


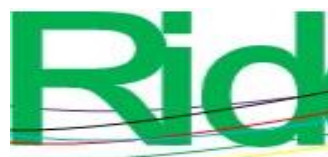

Revista Iberoamericana para la

Investigación y el Desarrollo Educativo

ISSN $2007-7467$

standards of a researcher are formed by three factors: academic degree, experience as researcher and publications in indexed journals. Professors should be researchers as these two roles are closely related. These two activities combined allow to observe problems from a different perspective. Some scenarios trouble the teacher, but encourage and inspire the researcher. In the literature reviewed, experiences from teachers who have implemented courses to motivate students to write a dissertation were found. These courses were given several years ago until these days. Some of them were focused on teaching writing or developing skills in online programs. All these courses reported positive outcomes, except for one in which students were not committed and the institution did not give the appropriate support.

In the language teaching area, Reyes and Hernández (2014) identified the academic production of language teachers. They found that only a few of these professors have a Doctoral Degree and they are the ones who conduct research. Most teachers only have a Master's Degree, and their programs were focused on teaching, not research. This explains why there is not sufficient research in the area. In addition, the language teaching field has been focused on teaching and its evolution has been slow because tutoring and teaching consume most of the time to the teachers in the area.

Institutions evidently need researchers and need to provide the adequate conditions. Contrary to the expectations, there are few researchers in Latin America and the number of students who write a dissertation is also low. In Venezuela, Valarino and Yáber (2002) designed several interventions to improve students' writing, which reduced their blockings and improved their production, and developed their writing and researching skills. These authors also considered that blocking is a self-defense system to reduce the tension towards a long task. It is also another way to handle negative feelings, fear to criticism, to failure or need of perfection. All these feelings are also triggered by research and many researchers are not patient enough to write a report, have bad habits for working, lack of inspiration to write, deficient writing skills or reject the idea of writing.

Gheller de Reif (2002) also designed a strategy in Venezuela to avoid the ABD syndrome and made an action research study. This strategy helped students to decide and choose a topic for their dissertation. The author had some difficulties like lack of compromise from the students, no support at all from the institutional authorities, difficulties to find a chair person. In 2006, GarcíaCalvo dictated an online workshop for students writing dissertations and had positive outcomes, like minimizing isolation, contacting $\mathrm{ABD}$ students, diminish procrastination, offer solutions to time management problems and teach strategies to avoid the writer's block. 


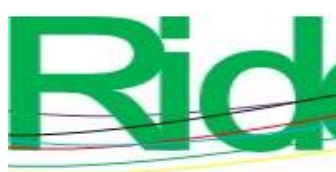

Revista Iberoamericana para la

Investigación y el Desarrollo Educativo

ISSN $2007-7467$

In 2008, in Argentina, Carlino implemented the peer evaluation technique to motivate students to write a dissertation, which requires methodological skills not previously developed. It also demands perseverance to failure, tolerance to ambiguity and developing unknown writing patterns. In Colombia, Landazábal, Páez and Pineda (2013) dictated a course to train researchers online. They classified the skills to perform scientific activities as higher (problem solving, developing theories and creativity), intermediate (offering solutions, implementing the project, doing proceedings, transforming the object of study and exercising ethics) and basic (observation, experimentation, surveying, exploration, description, stating objectives, making hypothesis, comparisons, searching information, analysis, synthetizing information, selecting and applying methodologies, planning, evaluating, writing, team work and oral presentations).

In Paraguay, a country where scientific research has not been developed significantly, a program to train researchers was developed. Spinzl, Sosa, González and Aquino (2015) mentioned that the conditions for academic production are limited, that there is a need of trained researchers and that Paraguay has the lowest punctuations in research. Even if the course contents are related to methodology contents, there is a separation between them. In this intervention, activities that do not encourage research were identified, they make recommendations and highlight the importance of the student-chair academic and emotional relationship.

\section{Conclusions}

The low attitude of students in the institution of the study is understandable considering the institutional conditions and the opinions they behold of their teachers. It was demonstrated that they do not know the research groups and their activities, as they do not participate in research projects and neither do they consider that the conditions to conduct research are adequate. Students also pointed out that teachers do not present their academic publications in class, which could be due to the fact that they do not conduct research and neither do they publish. They also consider that teachers do not adequately tutor them in these activities or invite them to participate in their projects. It would be suitable to conduct a future research to detect if the problem is presented only in the school of the study or if the other schools and colleges of the same university have this same problem. The data gathered in this research would help to design an intervention to improve the institutional conditions so they encourage professors and students to conduct research.

It would also be recommended to establish criteria to encourage professors to train 


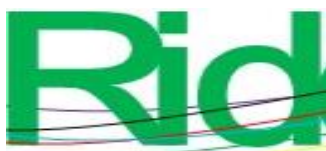

Revista Iberoamericana para la Investigación y el Desarrollo Educativo

ISSN $2007-7467$

themselves as researchers and publish, specially professors who teach methodology subjects. If this criterion were established, the institution would have researchers training researchers as the literature consulted suggests. This is a serious problem that affects institutions, pertinence of educative programs and former students. A student who does not obtain a degree can have personal problems derived from this situation and do not have access to several job opportunities. The society is also affected because universities should be training highly trained experts. The objective of the educational program of this study is to train language teachers who will have to conduct research in their professional life in order to get tenure track, promotions and laboral benefits. Professors are preparing people for the future, unfortunately, schools and faculty are under pressure to preserve the traditional system, which is unable to innovate and do not encourage students towards this direction. 


\section{References}

Abousky, A., Alfaro, J., \& Ramírez, M. (octubre, 2012). Relaciones interpersonales virtuales en los procesos de formación de investigadores en ambientes a distancia. Sinéctica, 39, 1-14.

Bandura, A. (2000). In A. E. Kadzin (Ed.), Self-efficacy. Washington: American Psychological Association, American Psychological Association Oxford University Press.

Doi:http://dx.doi.org.ezproxylocal.library.nova.edu/10.1037/10522-094

Bandura, A. (2000). In A. E. Kadzin (Ed.), Social-cognitive Theory. Washington: American Psychological Association, American Psychological Association Oxford University Press. Doi:http://dx.doi.org.ezproxylocal.library.nova.edu/10.1037/10522-140

Cisternas, T. (julio, 2013). Contextos, contingencia e intereses en el proceso de investigar la formación docente. Un estudio de caso. Calidad en la educación, 38, 115-146.

Colorado, B., \& Edel, R. (enero, 2012). La usabilidad de TIC en la práctica educativa. RED, Revista de Educación a Distancia, 30, 1-11.

Creswell, J. W., \& Plano Clark, V. (2018). Designing and conducting mixed methods research. Thousand Oaks, California: Sage.

Deaton, S. (june, 2015). Social learning theory in the age of social media: implications for educational practitioners. I-manager's Journal of Educational Technology, 12(1), 1-5.

Edel, R. (enero, 2010). Entornos virtuales de aprendizaje. La contribución de "lo virtual” a la Educación. RMIE, (15)44, 7-15.

Frugoni, A. (2014). El rol del docente en la universidad: su participación en la promoción de la investigación académica. Revista de Derecho de la Universidad de Montevideo, 26, 73-81.

Gairín, J. (2011). Formación de profesores basada en competencias. Bordón, 63, 93-108.

Gutiérrez, N. (junio, 2014). Producción de conocimiento y formación de investigadores. Sinéctica, 43, 1-16.

Hernández Sampieri, R., Fernández Collado, C., \& Baptista Lucio, P. (2014). Metodología de la investigación. México, D.F.: McGraw-Hill Education.

Jornet, J., González, J., Suárez, J., \& Peraless, M. (2011). Diseño de procesos de evaluación de competencias: consideraciones acerca de los estándares en el dominio de las competencias. Bordón, 63, 125-145.

Kranke, D., Brown, J., Atia, M., \& Knotts, G. (2015). A pedagogical approach to engaging social work students in research. Social Work Education, 34(7), 895-901. 


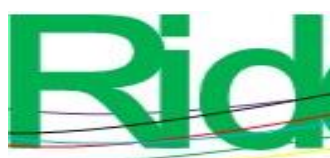

Landazábal, D., Páez, D., \& Pineda, E. (septiembre, 2013). Diseño de una innovación pedagógica para la formación en investigación apoyada en ambientes digitales. Revista Virtual Universidad Católica del Norte, 40, 4-30.

Martínez, B., Sosa, D., Alfaro, J., \& Ramírez, M. (enero, 2012). Procesos de gestión de información y construcción de conocimiento en la formación de investigadores educativos a través de ambientes a distancia. Sinéctica, 38, 1-15.

Moreno, M. (abril, 2012). La formación de investigadores como elemento para la consolidación de la investigación en la universidad. Revista de la Educación Superior, (2)158, 59-78.

Obermeier, M. L. (2017). Índice de actitud hacia la investigación y disposición a la titulación por tesis. (Doctoral dissertation). Retrieved from MARPS, Practicum and Applied Dissertations. (12274)

Olson, M. H., \& Hergenhahn, B. R. (2013). An introduction to theories of learning. (9th Ed.). New York: Routledge.

Pérez-Reveles, M., Topete-Barrera, C., \& Rodríguez-Salazar, L. (julio, 2014). Modelo para la formación y el fortalecimiento de investigadores en las universidades. Revista Investigación Administrativa, (43)114, 82-95.

Pérez, A., \& Guzmán, M. (junio, 2015). Narrativa de los profesores investigadores en torno a las tensiones generadas por las condiciones laborales y evaluación de la productividad académica. Administración y Organizaciones, (18)34, 93-112.

Reyes, M., \& Hernández, E. (marzo, 2014). Productividad y condiciones para la investigación: el caso de los profesores de lenguas extranjeras. Sinéctica, 42, 1-17.

Rietvieldt, F., \& Vera, L. (mayo, 2012). Factores que influyen en el proceso de elaboración de la tesis de grado. Omnia, (18)2, 109-122.

Romo, A., Villalobos, M., \& Arias, L. (enero, 2011). Gestión del conocimiento: estrategia para la formación de investigadores. Sinéctica, 38, 1-20.

Sanderse, W. (2013). The meaning of role modelling in moral and carácter education. Journal of Moral Education, 42(1), 28-42.

Spinzl, C., Sosa, D., González, L., \& Aquino, B. (junio, 2015). A investigar se aprende investigando. Programa de jóvenes investigadores. Sinéctica, 44, 1-11.

Torres, L. (enero, 2014). Investigación en la maestría. Tecnología, Investigación y Academia, (1)2, 117-130. 


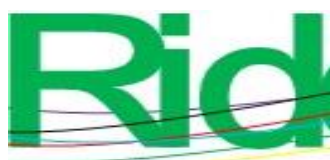

Uribe, I., Márquez, C., Amador, G., \& Chávez, A. (enero, 2011). Percepción de la investigación científica e intención de elaborar tesis en estudiantes de psicología y enfermería. Enseñanza e Investigación en Psicología, (16)1, 15-26.

Valarino, E., \& Yáber, G. (2002). Overcoming researcher's block symptoms: creative strategies for research. Revista Interamericana de Psicología, (36)182, 63-79.

Valarino, E., Yáber, G., \& Cemborain, S. (septiembre, 2011). Diseño curricular por competencias, postgrado y TMT (todo menos tesis). Manuscrito inédito, reunión del núcleo de autoridades de postgrado. Universidad Simón Bolívar. Caracas, Venezuela. 